\title{
Growing up (being) without a mother: children's experiences during maternal imprisonment
}

\author{
(Cre)scendo na ausência da mãe: vivências de crianças durante o cárcere materno \\ Crecer(ser) en ausencia de la madre: experiencias de los niños durante el encarcelamiento materno
}

'Universidade Estadual de Campinas. Campinas, São Paulo, Brazil. "Universidade Federal de São Paulo. São Paulo, São Paulo, Brazil.

How to cite this article:

Melo LL, Ribeiro CA. Growing up (being) without a mother: children's experiences during maternal imprisonment.

Rev Bras Enferm. 2020;73(Suppl 4):e20200413. doi: http://dx.doi.org/10.1590/0034-7167-2020-0413

\section{Corresponding author: \\ Luciana de Lione Melo E-mail: Iulione@unicamp.br}

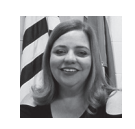

EDITOR IN CHIEF: Antonio José De Almeida Filho ASSOCIATE EDITOR: Fátima Helena Espírito Santo

Submission: $04-29-2020$

Approval: 07-15-2020

\begin{abstract}
Objective: to understand, through dramatic therapeutic play, children's experiences during maternal imprisonment. Methods: this is a phenomenological study in the light of Winnicott's theoretical framework carried out in a philanthropic assistance center in the capital of São Paulo, with eight children aged three to ten who participated in an interview mediated by dramatic therapeutic play session. Results: two categories emerged: Children being without a mother: a storm with lightning and thunder and Children growing up without a mother: drizzle, heavy rain and some rays of sun. Final considerations: children revealed that, even in the absence of their mothers, it is possible to continue being and growing. Therapeutic play allowed children to give voice to their experiences, surrounded by concerns and limitations, in addition to unveiling an unknown social context.

Descriptors: Child; Mother-Child Relations; Prisons; Play and Playthings; Pediatric Nursing.
\end{abstract}

\section{RESUMO}

Objetivo: compreender, por meio do brinquedo terapêutico dramático, as vivências de crianças durante o cárcere materno. Métodos: trata-se de um estudo fenomenológico à luz do referencial teórico de Winnicott, realizado em um centro assistencial filantrópico da capital paulista, com oito crianças de três a dez anos que participaram de entrevista mediada por sessão de brinquedo terapêutico dramático. Resultados: emergiram duas categorias temáticas: $A$ criança sendo sem a mãe: uma tempestade com raios e trovões e $A$ criança crescendo sem a mãe: garoa, chuva forte e alguns raios de sol. Considerações finais: as crianças revelaram que, mesmo na ausência da mãe, é possível continuar sendo e crescendo. O brinquedo terapêutico permitiu que as crianças dessem voz às suas vivências, cercada de preocupações e limitações, além de desvelar um contexto social desconhecido.

Descritores: Criança; Relações Mãe-Filho; Cárcere; Jogos e Brinquedos; Enfermagem Pediátrica.

\section{RESUMEN}

Objetivo: comprender, a través del juguete terapéutico dramático, las vivencias de los niños durante el encarcelamiento materno. Métodos: se trata de un estudio fenomenológico a la luz del marco teórico de Winnicott, realizado en un centro asistencial filantrópico de la capital paulista, con ocho niños de tres a diez años que participaron de una entrevista mediada por una sesión de juego terapéutico dramático. Resultados: surgieron dos categorías temáticas: El niño sin la madre: una tormenta con relámpagos y truenos y El niño que crece sin la madre: llovizna, lluvia intensa y algunos rayos de sol. Consideraciones finales: los niños revelaron que, incluso en ausencia de la madre, es posible seguir siendo y creciendo. El juego terapéutico permitió a los niños dar voz a sus vivencias, rodeados de inquietudes y limitaciones, además de desvelar un contexto social desconocido

Descriptores: Niño; Relaciones Madre-Hijo; Prisiones; Juego e Implementos de Juego; Enfermaría Pediátrica. 


\section{INTRODUCTION}

The Brazilian prison system has 726,712 individuals deprived of their liberty, of which 42,355 are women ${ }^{(1)}$. From 1990 to 2016, the increase in the female population was $567.4 \%$, while the male population was $220.2 \%$, showing the upward curve of a mass incarceration of women ${ }^{(2)}$.

The imprisoned Brazilian women are young mothers, answer for the family support, have low education, come from socially economically disadvantaged strata and perform informal work activities in the period prior to prison. Approximately $68 \%$ have criminal ties for involvement in drug trafficking, with most playing a supporting role in crime ${ }^{(2)}$.

In general, incarcerated women are single, mothers and singleparent heads of family. After imprisonment, children are under tutelage of grandparents, especially maternal ones. They seek to maintain family ties, preferring to be in prisons without access to study and work, which assist in remission of the sentence, as long as close to family members ${ }^{(3)}$.

One of the guiding principles of the Brazilian National Policy for Attention to Women in Deprivation of Liberty and Leaving the Prison System (PNAMPE - Política Nacional de Atenção às Mulheres em Situação de Privação de Liberdade e Egressas do Sistema Prisional) is assistance modalities, actions that must be developed in prison. Among these actions, there is reference to attention to children/ mother-child bond, which provides for a special visitation day for children who are outside the prison unit. Visits must be in appropriate spaces and planned by a multidisciplinary team ${ }^{(4)}$.

In addition to PNAMPE, Brazil must comply with the Bangkock Rules $^{(5)}$ and the Child and Adolescent Statute ${ }^{(6)}$ (ECA - Estatuto da Criança e do Adolescente) recommendations; such recommendations emphasize the importance of opportunity for mother and child to meet, although this does not occur in prison life.

In Brazil, there is no specific data on how children of incarcerated women live. A study carried out in a female prison in the state of São Paulo, with 150 women, showed the existence of 441 children, with an average age of 7.5 years; in $20 \%$ of cases, the parents were also incarcerated. Only $53.3 \%$ of children learned of maternal prison; of these, $24 \%$ were sad and inconsolable ${ }^{(7)}$.

Children of imprisoned mothers are predisposed to greater risks of maladjustment ${ }^{(8-9)}$. Therefore, American, British and Australian institutions have sought, through programs, to strengthen family ties, recognizing the special needs of mothers and children. Objectives include improving parenting skills and reducing conflicts between caregivers and mothers ${ }^{(10-11)}$.

The Extended Family Visit Program, implemented in an American penitentiary, allows extended visits on Saturdays and group activities organized by mothers. The benefits indicated were the opportunity to build and maintain a relationship with the children, motivation and personal growth ${ }^{(12)}$.

However, programs aimed at maintaining the relationship of incarcerated mothers with their children are non-existent in Brazil. Moreover, there is no scientific production and/or institutional websites that describe initiatives with this purpose.

Thus, considering the importance of children's health, we believe that understanding children's experiences during maternal imprisonment will enable propositions that embrace children and mothers in prison in the fields of teaching, care and research in pediatric nursing.

\section{OBJECTIVE}

To understand, through dramatic therapeutic play, children's experiences during maternal imprisonment.

\section{METHODS}

\section{Ethical aspects}

This study was approved by the assistance center board where it was carried out and by the Research Ethics Committee of Universidade Federal de São Paulo.

Children's guardians attend the institution, when they were informed about the study purpose. After guardians signed the Informed Consent Form (ICF), children were invited to play by presenting the Child's Consent Term, explaining the research through drawings designed for this purpose.

Children who agreed to participate were invited to Dramatic Therapeutic Play (DTP) sessions, which took place in a private room at the care center. Secrecy and anonymity were ensured, with their names replaced by names of characters from fairy tales chosen by themselves.

During research development, all ethical aspects were respected for research involving human beings recommended by Resolution CNS (Conselho Nacional de Saúde - Brazilian National Health Council)/Ministry of Health 466/12 of the Brazilian National Commission of Ethics in Research (CONEP - Comissão Nacional de Ética em Pesquisa) ${ }^{(13)}$.

\section{Type of study and theoretical framework}

This is a phenomenological study; as a theoretical framework, essential concepts about human being emotional development contained in the works of Donald Woods Winnnicott were adopt$\mathrm{ed}^{(14)}$. Winnicott's psychoanalysis can support phenomenological research, because Winnicott, like Heidegger, understands care in an integrative way. Winnicott understands human beings not as objects of nature, but as people who, in order to exist, need the care and attention of other human beings ${ }^{(15-16)}$.

Babies are born with inherited tendencies that lead them to grow. Mother and baby gradually become familiar with each other, and development is happening, although it depends on a satisfactory environment. An environment is considered satisfactory when it adapts to the child's individual needs. Bing an/a 'ideal mother' or 'good enough mother' refers to meeting a child's needs, and a mother is usually able to do so ${ }^{(14)}$.

Thus, development is a continuous process that takes place in absolute dependence, relative dependence and relative autonomy. Therefore, the care that parents give to babies is an absolute necessity, as a baby deprived of affection may have emotional problems as they grow ${ }^{(17)}$.

However, receiving affection does not mean a life without tears. Even the most loving and understanding family environment does not last forever, which does not necessarily mean problems. A 
healthy child can use any resource that nature offers to defend against anguish and conflict, and as they grow up, they will find new resources. Play is one of those resources ${ }^{(18)}$.

Children look for other children, because playing allows emotional relationships, it is pleasant, but it also collaborates in the domain of anxieties. Excessive anguish leads to repeated play and can be compulsive. Children also play to get rid of hatred and aggression. Playing is beneficial when expressed in an acceptable manner. Thus, children feel that they are being honest and that they do not have to hide what they feel. Thus, children acquire internal and external experiences by playing ${ }^{(18)}$.

Thus, Winnicott sees play as universal, as health, because playing facilitates development, leads to group relationships and is a form of communication ${ }^{(19)}$. In this context, playing was a natural way to access children's experiences during maternal imprisonment.

This investigation was conducted and structured with reference to the Consolidation Criteria for Reporting Qualitative Research (COREQ) ${ }^{(20)}$.

\section{Methodological procedures}

The phenomenological interviews were mediated by DTP sessions, a structured technique that allows understanding the children's feelings and emotional reactions ${ }^{(21)}$. Through DTP, children express feelings and relive unpleasant situations, in an attempt to master them. It can be used for any child and in any place that is convenient, and each session can vary from 15 to 45 minutes $^{(22)}$.

The DTP sessions lasted 45 minutes; they were held by one of the researchers, individually or in pairs, when children were siblings, without the presence of families, at their option. The sessions started without question regarding maternal prison still at the request of their relatives, only with an invitation to play, which is not an obstacle to the phenomenological method, since children were launched into the world that involves maternal prison ${ }^{(23-24)}$.

The material used for DTP sessions was packed in a plastic box, containing cloth dolls representing the family (grandparents, parents, children), plastic dolls, puppets, animals, household items, strollers, graphic material. These toys were selected from the specific literature recommendations, in order to provide the child with conditions to dramatize significant situations ${ }^{(21)}$.

\section{Study setting}

This study took place at a philanthropic assistance center based in the capital of São Paulo. It is an entity whose purpose is to provide medical, dental and socio-educational assistance to the population.

\section{Data source}

Eight children between the ages of three and ten participated in the study, who were experiencing maternal imprisonment, as indicated by the social worker, nurse and pedagogue of the referred assistance center. Chart 1 shows children with their respective fictitious names, their ages, time away from mothers and guardians.

\section{Data collection and organization}

Chart 1 - Children participating in the study, São Paulo, Brazil, 2020

\begin{tabular}{|c|c|c|c|c|}
\hline Guardian & Child/Age & $\begin{array}{c}\text { Reason for } \\
\text { maternal } \\
\text { imprisonment }\end{array}$ & $\begin{array}{l}\text { Time mothers } \\
\text { have been } \\
\text { away }\end{array}$ & $\begin{array}{l}\text { Number } \\
\text { of DTP } \\
\text { sessions }\end{array}$ \\
\hline $\begin{array}{l}\text { Family } 1 \\
\text { Paternal grandmother }\end{array}$ & Peter Pan - 4 years old & $\begin{array}{l}\text { Drug } \\
\text { trafficking }\end{array}$ & 4 years & $\begin{array}{l}2 \text { DTP } \\
\text { sessions }\end{array}$ \\
\hline $\begin{array}{l}\text { Family } 2 \\
\text { Maternal grandmother }\end{array}$ & $\begin{array}{l}\text { Aladdin }-9 \text { years old } \\
\text { Simbad - } 10 \text { years old }\end{array}$ & $\begin{array}{l}\text { Drug } \\
\text { trafficking }\end{array}$ & 5 years & $\begin{array}{l}2 \text { DTP } \\
\text { sessions in } \\
\text { pairs }\end{array}$ \\
\hline $\begin{array}{c}\text { Family } 3 \\
\text { Paternal aunt }\end{array}$ & Cinderella - 9 years old & $\begin{array}{l}\text { Theft followed } \\
\text { by muder }\end{array}$ & 6 years & $\begin{array}{l}17 \text { DTP } \\
\text { sessions }\end{array}$ \\
\hline $\begin{array}{l}\text { Family } 4 \\
\text { Paternal grandmother }\end{array}$ & $\begin{array}{l}\text { Hansal }-5 \text { years old } \\
\text { Gretel }-7 \text { years old }\end{array}$ & $\begin{array}{l}\text { Drug } \\
\text { trafficking }\end{array}$ & 2 years & $\begin{array}{l}7 \text { DTP } \\
\text { sessions in } \\
\text { pairs }\end{array}$ \\
\hline $\begin{array}{l}\text { Family } 5 \\
\text { Maternal grandmother }\end{array}$ & $\begin{array}{l}\text { Little Red Riding Hood } \\
3 \text { years old }\end{array}$ & $\begin{array}{l}\text { Drug } \\
\text { trafficking }\end{array}$ & 2 years & $\begin{array}{l}10 \text { DTP } \\
\text { sessions }\end{array}$ \\
\hline $\begin{array}{l}\text { Family } 6 \\
\text { Maternal grandmother }\end{array}$ & $\begin{array}{l}\text { Snow White } \\
9 \text { years old }\end{array}$ & $\begin{array}{l}\text { Drug } \\
\text { trafficking }\end{array}$ & 2 years & $\begin{array}{l}3 \text { DTP } \\
\text { sessions }\end{array}$ \\
\hline
\end{tabular}

All interviews mediated by DTP took place from March 2015 to December 2016, were recorded on a digital recorder, and children's behaviors were recorded in a field diary, since filming can mischaracterize the phenomenon's original form ${ }^{(23-25)}$. The transcriptions of DTP sessions took place shortly after their end.

The number of DTP sessions varied among children according to the availability of their relatives. However, all children had a closing session to understand the end of the activity.

\section{Methodological framework and data analysis}

DTP sessions, together with the descriptions of each child's field diary, were considered phenomenological discourse, organized according to the steps of phenomenological research: description - it is the moment when the researcher, through awareness, questions and describes the phenomenon; reduction - from intuitive reflection, the phenomenon's essence is reached; understanding, which is the interpretation of the phenomenon, i.e., when the researcher takes ownership of the phenomenon and projects it ${ }^{(24)}$.

DTP sessions ended when speeches proved to be consistent and sufficient, i.e., when theoretical saturation was reached, which means that from the description and reduction, through a constant analytical process, researchers observed that new elements ceased to appear in the play. At this moment, theoretical density is palpable enough to reveal a phenomenon, in the researcher's perspective ${ }^{(26)}$. 
Two thematic categories have emerged: Children being without a mother: a storm with lightning and thunder and Children growing up without a mother: drizzle, heavy rain and some rays of sun.

\section{RESULTS}

\section{Children being without a mother: a storm with lightning and thunder}

Children represent the new journey, explaining, in play, the sudden changes that occurred after maternal imprisonment. They move to other homes, usually the maternal grandparents, live with other family members and/or households they already knew, but do not often meet or even with strangers, who did not participate in their daily lives. In a new residence, the bed, the bedroom, the bathroom, the food, the toys, the rules, are all new, everything causes strangeness.

Child (C) plays house, makes food for boy and girl dolls. Give voice to both dolls, now as a boy, now as a girl, and say, as a girl: let's have lunch? Lunch is ready, but here there are no beans and no tomatoes. Here is the other house. The boy answers: what house is this? Girl: I never came to this house, it's your father's mother (Gretel, 7 years old).

Child arranges the kitchen toys: I will make chocolate milk. Oh no, I forgot, there's only coffee here (Little Red Riding Hood, 3 years old).

Snow White arranges all the toys organizing the bedroom, living room and kitchen. In the bedroom, he puts his grandparents, the boy, the dog and the baby on the bed. Take a towel and stretch it in the room. Look at the researcher and say: the room is very full. She sleeps in the living room, but she doesn't have a bed, just a comforter and it gets really hard, but one day she'll be back.

\section{R: back?}

C: back home when her mother is free. Her mother is imprisoned, grounded, she fought with the guard [...]. Now she can't leave, she misbehaved (Snow White, 9 years old).

In addition to home, children start studying in new schools, where other children and teachers are unknown and need to adapt. Some may go without studying for months, as there are no vacancies and/or those responsible cannot afford to buy the new school supplies and the necessary uniforms.

Cinderella starts the DTP session by arranging the toys: let's play school. I'm the teacher and you're the new girl, okay?

R: what do / do?

C: you will enter the class and say good morning to teacher Marta, you can start.

R: good morning, teacher Marta.

C: good morning, what is this outfit? Don't you have a uniform? Do not you? Because you have changed schools now. But tell your grandmother to buy it right away because in this school you have to wear a uniform and you have to bring the complete material because nobody can borrow it. Sit here by my desk and do this lesson.

I sit the doll down and take the pencil she hands me with a sheet.

C: don't you know? Didn't they teach you anything at the other school? I will teach you, but you have to pay attention and be quiet (Cinderella, 9 years old).

Simbad explores the toys and asks the researcher: a 10-year-old child has to be in which grade?

R: in which grade?

C: $5^{\text {th }}$ grade, $4^{\text {th }}$ grade, but I was late. I moved house and didn't go to the new school. There was no vacancy, baby got mine.

R: baby?

C: yeah, the baby is the owner.

R: owner of what?

C: from slum. He gave my grandmother a market basket. He helps because he is the owner, where I lived there was no owner (Simbad, 10 years old).

A child, without a mother, gets to know new realities. Snow White reports knowing why her mother is absent. Peter Pan's grandmother, on the other hand, says that he was delivered to her eight days old and that he never spoke about his mother to him. However, playing Peter Pan, it was possible to show the opposite.

Child opens the toy box and begins to explore them. When he finds the handcuffs, he gets very excited. He takes them, come to me across the table: put your hands back now [speaks yelling]. I put my hands on my back. The child handcuffs me and says: you're under arrest because you stole it.

\section{R: what now?}

C: you will be without your mother (Peter Pan, 4 years old).

Peter Pan's mother was arrested for theft, which shows that even when a child is not told why his mother is absent, he or she gradually observes adults around her or him and their conversations. Thus, she or she gathers the information, piece by piece, as in a puzzle, finding answers to maternal absence. Another novelty exposed by Simbad is that the environment where he lives with his grandmother has an "owner". This is the "head" of drug trafficking where his grandmother lives.

Thus, in addition to the changes imposed by maternal imprisonment, some children are exposed to other vulnerabilities, such as living in an environment controlled by individuals responsible for drug trade.

How older children play, as they understand the new reality and what caused it, brings frightening symbols, such as storms, lightning and thunder, which allows us to understand the size of the impact of maternal imprisonment. 
Gretel arranges her toys for a backyard party: let's have a barbecue, a party to celebrate. Celebrate the family, all together, eating, laughing, children playing, lots of people, siblings [...]. They were very happy, but suddenly the sun went away and the storm started, there was lightning and thunder, it flooded everything and took all happiness. It was so much change that there was even a fire. Now they live in favor and without a mother (Gretel, 7 years old).

Snow White draws a garden on a leaf and then puts the drawing as a backdrop: look what a beautiful house, even a garden! Children are playing soccer. The family is inside the house [...] she takes green, yellow and red play doughs and makes balls for children to play. She takes the black play dough and 'snakes' around the kids. Run, run, take the children inside, it's lightning and thunder. The mother was arrested, it is going down, without the mother, it goes down (Snow White, 9 years old).

It is possible to perceive the role that a mother plays in the domestic routine, even if, at times, it is permeated by illegal activities, such as drug trafficking.

Peter Pan 'builds' two buildings with the building blocks with a road between them. Two cars come and go on this road: the cars go there.

R: where?

C: in the sheriff's building, but he doesn't let in, so the blue cart comes home. The red car goes over to the sheriff's building, but he won't let it in again, so he goes home. You can never enter (Peter Pan, 4 years old).

Aladdin organizes the toys in a house and a forest with animals. Put the doll on top of the truck and go from the house to the forest. When he gets there, the doll goes down, but when the lion roars, the doll runs, gets on the truck and goes home. The doll takes this path several times and Aladdin remains silent. After approximately 20 minutes, Aladdin has the frontal region of his head with several sweat droplets. He sighs loudly and speaks: it doesn't work, the lion doesn't let the boy get close, he's dangerous and the forest is dangerous too. No one can get close, like the building my mom is in, it's dangerous too. He makes the doll come home, lays him on the bed, prone, with his head hidden by his arms.

\section{R: what happened to him?}

C: he is exhausted [sighs again] (Aladdin, 9 years old).

If a child does not have a mother, other family members are called, but their participation must be temporary. Cinderella, in one of her school games, dramatizes a conversation between her teacher and her aunt.

C: I will be teacher Marta on the day of the meeting and you will be the aunt.

R: and what do I say to Professor Marta?

C: you say you want to know about Vanessa, if she is learning and if she got a good grade. Let's start. Child takes the two female dolls, keeps one and hands the other to the researcher and says: good morning everyone, I will talk to all the mothers and aunts and tell them about the grades. Did you come to know about Vanessa?

R: yes, did Vanessa get good grades?

C: are you her mother?

$\mathrm{R}:$ no, I'm the aunt.

C: does she live with you while her mother is in prison? [whispers]

R:yes.

C: she took bad and good grades, but now she's better, because she was very sad, she didn't pay attention, but I put her sitting next to me so she wouldn't repeat a grade. But when her mother comes back, she'll get even better. Tell her to do the whole lesson, which I give stars. [speaking screaming]

$\mathrm{R}:$ I will speak.

Cinderella breaks up the school and organizes another game. As she arranges the toys for another game, there are tears in her eyes and she wipes them away.

R: do you want to stop playing?

C: no, I want to continue, I want to tell you more [...] (Cinderella, 9 years old).

Hansel and Gretel express concern about financial issues.

Gretel arranges her toys: let's play supermarket. She takes money notes and organize them for equal amounts. Lady, if that money were real, could you buy a house? [...] we are homeless, living in favor; our shack caught fire, burned everything, my notebooks, my backpack, Hansal's uniform, my grandmother's clothes. If I had money, I would buy a house.

Hansal: I couldn't even buy a house with those coins [shows the plastic coins]. My tennis shoes were burned down too, my grandfather is building another shack, but it will take a while because the material is expensive.

Gretel takes the paper money, puts it at her side with the gun on top.

\section{$\mathrm{R}:$ what is this?}

Gretel: protection for money and for me. In life, you have to protect money and protect yourself (Hansal, 5 years old and Gretel, 7 years old).

In this new context, exposed to social vulnerabilities, Gretel verbalizes that having a firearm is necessary, not only to protect the patrimony, but also the person himself, which shows a feeling of insecurity. Thus, in the absence of a mother, faced with this new reality, sometimes, with limiting factors, children grow up. 


\section{Children growing up without a mother: drizzle, heavy rain and some rays of sun}

After the different experiences that children have as a result of maternal imprisonment, it is necessary to reorganize internally to continue living. After all, there is no other way but to grow up, even without their mothers.

Along this path, in addition to family members, there are neighbors, friends, godparents, teachers. Although they do not always know what to do, they seek to help, which is already a consolation for children, as suffering is latent, emerging in the most different situations of vulnerability to which they are exposed.

Simbad arranges the toys: let's play commerce. Here will be the streets and here the stores. You work at that store, it will be the book, notebooks, paper, pencil and pen store. I will be the cops. I'll walk around the stores to see if nobody is stealing. Simbad puts the customer doll in the book store. Stares at the doll and approaches him: can I see your pockets? [Simbad speaks as a cop and as a customer].

C as a customer: I didn't do anything, sir.

C as a cop: then show me your pocket.

Simbad runs the customer doll and runs after it with the gun in his hands.

C as a cop: police, stop or I shoot. The doll continues to run and Simbad makes the sound of gunshots, the doll falls. He looks at me and says: he was robbing your store. He ran away, but now he's dead. He was a bandit, a thief. I saw a real dead thief near the subway. The cops were there. There were two thieves, one dead on the floor and the other with handcuffs, I don't know if he was a thief or if he was a drug dealer [...] (Simbad, 10 years old).

Gretel and Hansal play police and thief. She is the police and he is the thief by her decision. Although he doesn't like it, he accepts the joke. She handcuffs him: you will tell what you did [speaking screaming].

Hansal: I didn't do anything [speaks tearfully]. I don't want to play it, take it away from me [refers to handcuffs].

Gretel is very angry, removes the handcuffs and says, screaming: you can't come to play next day, understand?

Hansal does not answer, he is crestfallen. Gretel starts counting paper money aggressively. She talks to herself: if I had that money, I would send everyone. You did not obey me, I have you killed. She picks up the gun and points to the window.

Hansal: Grandma doesn't like that you talk like that.

Gretel: shut up, you are not my mother to rule over me and grandma is also not my mother to rule over me. Whoever had to do it is not here (Hansal, 5 years old and Gretel, 7 years old).

Children dramatize violent situations, and Gretel, from the first DTP session, showed moments of aggression. In one of the sessions, the grandmother asked to bring her alone, due to the aggressive behavior during the week.
Gretel arrives at the DTP session, doesn't greet me, enters the room, opens the toy box and starts exploring. She takes the money, the revolver, the scissors, the syringe, puts these objects on top of the money, takes a sheet of paper and scratches it hard, uses black pencil and then black gouache. She paints with her finger, paints four leaves with black gouache paint. This activity lasts approximately 20 minutes. She is sweating, sighs loudly and her legs dangle on the chair.

\section{R: Gretel, do you want to tell me what these drawings are?}

Gretel doesn't answer, he continues to paint the sheet with black gouache and, at a certain moment, the sheet tears. She is watching, static and starts to cry. First, in silence, then in tears, with your hands on her face. I put my chair next to hers and put my hand on her shoulder. When I feel my hand, it withdraws and I withdraw the hand, it remains crying. I try again to put my hand on his shoulder, and this time, Gretel allows. After a few minutes, she turns and hugs me. She cries convulsively, but gradually she calms down until she stops crying.

R: what are you feeling?

Gretel: I miss her a lot, my mother, my lung is hurting.

R: and when you feel it, what do you do?

Gretel: I hit Hansal, I hit anyone.

R: then what?

Gretel: I feel sad because I don't like to hit (Gretel, 7 years old).

It is possible to perceive Gretel's suffering, because, with seven years old, it is very difficult to live these experiences and come out unscathed. Even if the family welcomes them, they will not always feel at ease, as something will be missing and living with this gap is not easy for anyone, especially for children. Therefore, no day is the same as another. For some, there is only drizzle, in others, there is heavy rain, as exemplified by Cinderella.

Cinderella is excited, starts to draw, dividing the sheet in two parts. In one part, she makes flags with various colors and a candy stand. It makes little dots on the leaf. In the other part, she makes a black tree, paints the sky gray and makes rain, and draws for 15 minutes: what do you think of my drawing, aunt?

\section{R: beautiful.}

C: do you think both parts are beautiful?

R: do you think?

C: I like this part more [shows the colored part]. Do you know what this is? [refers to the drawing]. My life, here it rains hard and here thin rain, drizzle. Cinderella draws a sun on the colored side: and sometimes it has a little sun. Baby is the sun now and you are also the sun (Cinderella, 9 years old).

Plays leave no doubt of the suffering that permeates children's lives of incarcerated mothers. They are children trying to grow, 
trying to understand, trying to be in a world that is not always safe, with the most diverse threats, sometimes explicit, sometimes not so much. Without a mother, a gap in their stories opens up, which is gradually being filled with new discoveries intrinsic to child development; however, these moments, so bright for some children, do not have the same light for them. But life goes on, even though sometimes these children need flashlights to continue on their way.

\section{DISCUSSION}

In the children's play, the tortuous path emerged after their mothers' imprisonment emerged. Being without a mother and growing up without a mother are parts of this path, experienced, sometimes, with sadness and suffering. To travel this path, children tend to mature.

However, for Winnicott, the children's age at the moment they are separated from their mothers is an important factor for consequences that will come, since it is only from the age of two onwards that understanding expands and children start to interact with situations surrounding them ${ }^{(14)}$.

Some children did not live with their mothers during the whole phase of absolute dependence, such as Peter Pan, who was handed over to his paternal grandmother in the first week of life, and Little Red Riding Hood, who was one year old at the time of separation.

However, integration tasks in time and space continue even without a mother, with the help of a substitute. Keeping maturing places children facing challenges, such as maladjustment and disillusionment processes, which are beneficial because they drive them to understand that the world already existed before them and will continue to exist after their death ${ }^{(19)}$.

Playing, for Winnicott, takes place in a third area, intermediate between the internal reality and the external reality, although these two realities participate. It is the potential space, in which, by superimposing realities, children bring objects from external reality coated with symbolic meanings linked to the feeling of existence ${ }^{(19)}$, which was possible to learn in the play of all the children in this study.

The external reality was also exposed by children during playing. It concerns the new school, which is accompanied by new teachers and friends and their relationship with children. It is an unknown space and only with time will children feel familiar, as the experience repeats ${ }^{(27)}$. Another situation was Peter Pan's dramatization, when arresting the researcher for theft and affirming that when one is arrested this person stays without a mother, which exposed his understanding of maternal prison.

As a mother's absence occurred out of the blue, some children dramatized stories that explain the before and after, with and without a mother, as in the case of Gretel, which portrays a family party that ends with a storm, with lightning and thunder, and the Snow White case, which starts dramatization with children playing and later claims that without her mother "things go down".

What children want to represent, says Winnicott, is the real, the scary and the unacceptable of a reality ${ }^{(28)}$. Having mothers imprisoned and not being able to access it is unavoidable, as shown by Peter Pan and Aladdin, who after several attempts of approximation, without success, say they are exhausted.

If a child does not have a mother, due to needs intrinsic to childhood, other family members are called. Two "mothers" can represent, for a child, love and hatred, directed at one, now at the other ${ }^{(28)}$. Hatred can bring guilt and aggression. However, Winnicott does not believe that hatred and aggression are bad emotions. Satisfactory environments must tolerate the expression of these feelings in an acceptable way ${ }^{(18)}$.

Not having a mother also created financial difficulties. Hansal and Gretel insistently play with money, always bringing up the issue of being homeless, in addition to the need to use weapons to feel safe. These situations showed that the child does not always know how to differentiate between right and wrong.

Winnicott considers that the ideal is to acquire this concept naturally, as long as there are conditions for it. The basis of morality is the experience of the true self and the possibility of continuing to be. If by being themselves, mothers help them with their confidence, to dispel fears, children will be able to develop their own sense of right and wrong and mothers will only reinforce and enrich their children's ideas ${ }^{(28)}$.

Thus, more or less explicitly, children seek to appropriate their being, launching themselves into life only with the foundation of being alive and their tendency to mature, which for Winnicott is health ${ }^{(17)}$. A healthy individual's life is characterized by fears, conflicts, doubts, frustrations, and positive characteristics. The main thing is that children feel that they are living their life ${ }^{(14)}$.

To acquire this sense of existence, children played showing a world permeated by urban violence. For some children, aggressiveness was the way to move between not being able and being able, like Gretel, who was aggressive with her brother and with her own play, needing several DT sessions to feel safe and understand the environment as satisfactory.

Although observing a child's aggression can cause fear, aggression is psychically innate to every human being, as it is the one who shows individuals that they are alive. More worrying than aggressiveness itself is its repression. For Gretel, the environment was satisfactory, so that she could show, accept and integrate aggressiveness in her power to be. Without it, aggression would have to be hidden, which could result in violence or compulsion to destruction ${ }^{(29)}$.

For Winnicott, the human being is what his experiences provide, originated from his being in search of interaction with the world ${ }^{(29)}$; children, when playing, revealed their rich experiences of living without mothers, and playing itself collaborated in this interaction with the world.

\section{Study limitations}

The limitations are related to the difficulty in accessing children and reconciling guardians' schedule with research data collection, which, for some children, limited the number of DTP sessions.

\section{Contributions to nursing}

DTP use made it possible to reveal children's experiences during maternal imprisonment. Considering that DTP has a regulatory framework in nurses' work, it is necessary, in fact, to insert it as a 
theoretical and practical theme in undergraduate nursing courses. Training nurses to use this playful strategy implies not only a change in care, but also in research with children.

\section{FINAL CONSIDERATIONS}

This study sought to understand children' experiences during maternal imprisonment; what was revealed, through DTP, was a world surrounded by concerns and limitations as well as a little known and recognized reality as important for childcare.

There is evidence that the difficulties that children experience during maternal imprisonment can predispose to numerous emotional problems that are enhanced by the already existing vulnerabilities.
Without systematic health monitoring, problems emerge at school, which wear families out even more.

Creating programs that advocate the maintenance of the bond between mothers in prison and children is a major challenge for the Brazilian prison context, which does not understand prisoners as subjects of rights. But it is necessary to think beyond the crime, whose penalty is already being carried out, we must think about children, who need to be and grow as people, with dignity and comprehensive care.

\section{FUNDING}

This study received a National Quota Post-Doctoral Program Grant - PNPD/CAPES.

\section{REFERENCES}

1. Ministério da Justiça (BR), Departamento Penitenciário Nacional (DEPEN). Levantamento Nacional de Informações Penitenciárias: atualização junho de 2016. Brasília: MJ; 2017 [cited 2019 Apr 19]. 65 p. Available from: http://depen.gov.br/DEPEN/depen/sisdepen/infopen/ infopen

2. Ministério da Justiça (BR), Departamento Penitenciário Nacional (DEPEN). Levantamento Nacional de Informações Penitenciárias Infopen Mulheres: junho de 2014. Brasília: MJ; 2014. [cited 2019 Apr 19]. 42 p. Available from: https://www.justica.gov.br/news/estudo-traca-perfilda-populacao-penitenciaria-feminina-no-brasil/relatorio-infopen-mulheres.pdf

3. Centro pela Justiça e pelo Direito Internacional. Relatório sobre mulheres encarceradas no Brasil. Brasília; 2007[cited 2019 Apr 19]. 61 p. Available from https://carceraria.org.br/wpcontent/uploads/2013/02/Relato\%CC\%81 rio-para-OEA-sobre-Mulheres-Encarceradas-noBrasil-2007.pdf

4. Ministério da Justiça (BR). Departamento Penitenciário Nacional (DEPEN). Política Nacional de Atenção às Mulheres em Situação de Privação de Liberdade e Egressas do Sistema Prisional. Diário Oficial da União: República Federativa do Brasil; 2014. Jan 17, Seção 1: p. 75. [cited 2019 Apr 19]. 61 p. Available from: http://www.lex.com.br/legis_25232895_PORTARIA_INTERMINISTERIAL_N_210_DE_16_DE_JANEIRO_DE_2014.aspx

5. Conselho Nacional de Justiça (BR). Regras de Bangkok: regras das Nações Unidas para o tratamento de mulheres presas e medidas não privativas de liberdade para mulheres infratoras. Brasília; 2016. [cited 2019 Jan 29]. 24 p. Available from: https://carceraria.org.br/wpcontent/uploads/2012/09/Tradu\%C3\%A7\%C3\%A3o-n\%C3\%A3o-oficial-das-Regras-de-Bangkok-em-11-04-2012.pdf

6. Presidência da República (BR). Estatuto da Criança e do Adolescente. Brasília; 1990 [cited 2019 Jan 29]. 207 p. Available from: http://www. crianca.mppr.mp.br/arquivos/File/publi/camara/estatuto_crianca_adolescente_9ed.pdf

7. Ormeno GR, Fogo JC, Santini PM, Williams LCA. Children of incarcerated women in Brazil: vulnerability and traumatic experiences in their lives. JOLLAS. 2016;8(2):10-7. doi: 10.18085/1549-9502-8.2.10

8. Dallaire DH, Zeman JL, Thrash TM. Children's experiences of maternal incarceration-specific risks: predictions to psychological maladaptation. J Clin Child Adolesc Psychol. 2015;44(1):109-22. doi: 10.1080/15374416.2014.913248

9. Davis L, Shlafer RJ. Mental health of adolescents with currently and formerly incarcerated parents. J Adolesc. 2017;54:120-34. doi: 10.1016/j. adolescence.2016.10.006

10. Tremblay MD, Sutherland JE. The effectiveness of parenting programs for incarcerated mothers: a systematic review. J Child Fam Stud. 2017;26:3247-65. doi: 10.1007/s10826-017-0900-8

11. Miller AL, Weston LE, Perryman J, Horwitz T, Franzen S, Cochran S. Parenting while incarcerated: tailoring the strengthening families program for use with jailed mothers. Child Youth Serv Rev. 2014;44:163-70. doi: 10.1016/j.childyouth.2014.06.013

12. Schubert EC, Duininck M, Shlafer RJ. Visiting mom: a pilot evaluation of a prison-based visiting program serving incarcerated mothers and their minor children. J Offender Rehabil. 2016;55(4):213-34. doi: 10.1080/10509674.2016.1159641

13. Ministério da Saúde (BR). Resolução n CNS/MS 466/12. Dispõe diretrizes e normas regulamentadoras de pesquisas envolvendo seres humanos. Ministério da Saúde. Brasília: MS. [Internet]. 2012 [cited 2019 Feb 12]. Available from: http://conselho.saude.gov.br/ultimas_ noticias/2013/06_jun_14_publicada_resolucao.html

14. Winnicott DW. Tudo começa em casa. São Paulo: Martins Fontes; 2011. 304 p.

15. Loparic Z. Origem em Heidegger e Winnicott. Nat Hum[Internet]. 2007 [cited 2019 Oct 10];9(2):243-74. Available from: http://pepsic.bvsalud. org/scielo.php?script=sci_arttext\&pid=S1517-24302007000200002

16. Santos ES. Winnicott e Heidegger: indicações para um estudo sobre a teoria do amadurecimento pessoal e a acontecência humana. Nat Hum [Internet]. 2007 [cited 2019 Oct 20];9(1):29-49. Available from: http://pepsic.bvsalud.org/scielo.php?script=sci_arttext\&pid $=\mathrm{S} 1517-24302007000100002$ 
17. Dias EO. A Teoria do Amadurecimento. Rio de Janeiro: Imago; 2017. 328 p.

18. Winnicott DW. A criança e o seu mundo. Rio de Janeiro: LTC; 1982. 272 p.

19. Winnicott DW. O brincar e a realidade. Rio de Janeiro: LTC; 1975. 203 p.

20. Tong A, Sainsbury P, Craig J. Consolidated criteria for reporting qualitative research (COREQ):a 32-item checklist for interviews and focus groups. Int J Qual Health Care. 2007;19(6):349-57. doi: 10.1093/intqhc/mzm042

21. Green CS. Understand children's need through therapeutic play. Nurs. 1974;4(10):31-2.

22. Vessey JA, Mahon MM. Therapeutic play and the hospitalized children. J Pediatr Nurs [Internet]. 1990 [cited 2019 Feb 22];5(5):328-33. Available from: https://www.pediatricnursing.org/article/0882-5963(90)90004-S/pdf

23. Giorgi A. Phenomenology and psychological research. Pittsburgh: Duchesne University Press; 1985. 226 p.

24. Martins J, Bicudo MAV. A pesquisa qualitativa em psicologia: fundamentos e recursos básicos. São Paulo: Moraes; 2004.110 p.

25. Fonseca MRA, Campos CJG, Ribeiro CA, Toledo VP, Melo LL. Revealing the world of oncological treatment through dramatic therapeutic play. Texto Contexto Enferm. 2015;24(4):1112-20. doi: 10.1590/0104-0707201500003350014

26. Frank JR. I can't get no saturation: a simulation and guidelines for sample sizes in qualitative research. PLoS One [Internet]. 2017;12(7):e0181689. doi: 10.1371/journal.pone.0181689

27. Oliveira CL. Brincar para ser: um ensaio sobre a importância do direito fundamental de brincar na construção da subjetividade. Rev Bras Dir Gar Fundam [Internet]. 2015 [cited 2019 Apr 20];1(2):120-42. Available from: https://www.indexlaw.org/index.php/garantiasfundamentais/ article/view/744/0

28. Winnicott DW. Conversando com os pais. São Paulo: Martins Fontes; 2003. $170 \mathrm{p}$.

29. Dias EO. Winnicott: agressividade e teoria do amadurecimento. In: Sobre a confiabilidade e outros estudos. São Paulo: DWW Editorial; 2011. p. 89-123. 